\title{
DETEKSI Spodoptera frugiperda PADA TANAMAN JAGUNG DI KECAMATAN SABBANGPARU KABUPATEN WAJO
}

\author{
Detection Spodoptera frugiperda on the Corn Plant in Sabbangparu Regency Wajo District \\ Sulfiani $^{{ }^{*}}$, Sitti Aminah $^{2}$, Fitry Purnamasari $^{3}$ \\ ${ }^{1)}$ Agroteknologi, Fakultas Pertanian, Universitas Puangrimaggalatung \\ ${ }^{2) 3}$ Agribisnis, Fakultas Pertanian, Universitas Puangrimaggalatung \\ ${ }^{1 *}$ sulfianiridwan@gmail.com
}

\begin{abstract}
ABSTRAK
Tujuan penelitian ini untuk mengetahui pola penyebaran S. frugiperda di kecamatan Sabbangparu, Kabupaten Wajo. Penelitian dilaksanakan pada bulan Mei - Agustus 2021. Tahapan penelitian dengan menggunakan survey dan monitoring dengan metode scouting. Pengambilan Sampel setiap area pertanaman diambil contoh sampel tanaman jagung yang ditentukan secara sistematik. Sampel yang ditemukan dilapangan diambil dan dimasukkan kedalam wadah plastik untuk diidentifikasi bioekologi. Hasil survei menunjukkan bahwa S. frugiperda sudah menyerang tanaman jagung pada fase generatif dan vegetatif di semua Kelurahan dan Desa di Kecamatan Sabbangparu. Karakter spesifik yang terdapat pada $S$. frugiperda berupa huruf "Y" terbalik pada kapsul kepala dan pola titik hitam pada abdomen (titik empat dan trapesium). Stadia pertumbuhan yang diperoleh dilapangan yaitu stadia larva dan imago.
\end{abstract}

Kata kunci: S. frugiperda, jagung, pola sebaran

\begin{abstract}
The purpose of this study was to determine the distribution pattern of S. frugiperda in Sabbangparu sub-district, Wajo district. The research was carried out in May - August 2021. The research stages used surveys and monitoring with the scouting method. Sampling of each planting area, samples of corn plants were determined systematically. Samples found in the field were taken and put into plastic containers for bioecological identification. The survey results show that $S$. frugiperda has attacked maize plants in the generative and vegetative phases in all sub-districts and villages in Sabbangparu sub-district. Specific characters found in S. frugiperda are inverted " $Y$ " letter on the head capsule and black dot pattern on the abdomen (four dots and trapezoid). The growth stages obtained in the field were the larval and imago stages.
\end{abstract}

Keywords: S. frugiperda, corn, scatter pattern

\section{PENDAHULUAN}

Spodoptera frugiperda atau Fall

Armyworm (FAW) merupakan salah satu hama yang menyerang pertanaman jagung.

Pada awal 2016, untuk pertama kalinya hama ini ditemukan di Afrika Tengah dan Barat (Benin, Nigeria, Sao Tome dan
Principe, dan Togo). Kemudian ditemukan di seluruh daratan Afrika bagian Selatan (kecuali Lesotho), juga di Madagaskar dan Seychelles (Negara Kepulauan). Selanjutnya dilaporkan pada tahun 2018, FAW teridentifikasi dan dilaporkan menyerang di hampir seluruh negara Sub-Sahara Afrika. 
Perbal: Jurnal Pertanian Berkelanjutan

Fakultas Pertanian Universitas Cokroaminoto Palopo

Laporan petama adanya S.frugiperda di Kabupaten Pasaman Barat, Sumatera Barat, FAW telah ditemukan merusak pada tanaman jagung dengan tingkat serangan yang berat, populasi larva antara 2-10 ekor pertanaman. Di Lampung, juga telah dilaporkan serangan hama ini pada tanaman jagung (Nonci, 2019).

S. frugiperda memiliki tingkat kerakusan makan tanaman hingga 10 kali lipat dibanding spesies lokal. Selama ini untuk spesies lokal banyak makan diwaktu malam hari saja, sedang pada siang harinya tidur dan sembunyi. Sedangkan ulat frugiperdaselalu makan tanaman jagung di sepanjang waktu siang dan malam tak berhenti, hingga habis tanamannya dan apabila makanannya sudah habis maka bersifat kanibal, yakni memakan sesamanya (Sari, 2020).

Saat ini, keberadaan S. frugiperda di Kabupaten Wajo khususnya Kecamatan Sabbangparu belum dilaporkan secara ilmiah. Akan tetapi dari laporan petani dan petugas dilapangan, hama ini sudah ada di lokasi pertanaman jagung. Oleh karena itu, diperlukan tindakan monitoring, investigasi dan penelitian tentang pengendalian hama baru yang sangat penting ini untuk dilakukan pencegahan terjadinya ledakan hama.
Berdasarkan uraian di atas, maka penelitian tentang deteksi invasif $S$. frugiperda sebagai upaya untuk melaksanakan tindakan monitoring mengenai pola sebaran hama ini dipertanaman jagung di Kecamatan Sabbbangparu Kabupaten Wajo. Hasil dari penelitian ini dapat menentukan strategi pengendalian yang efektif.

\section{Tujuan Penelitian}

Penelitian ini bertujuan menginformasikan keberadaaan $S$. frugiperda yang menyerang tanaman jagung di Kecamatan Sabbangparu, Kabupaten Wajo.

\section{METODE PENELITIAN}

\section{Tempat dan Waktu}

Penelitian dilaksanakan di Kecamatan Sabbangparu, Kabupaten Wajo, Sulawesi Selatan. Penelitian dilaksanakan pada bulan Maret sampai September 2021.

\section{Bahan dan Alat}

Bahan yang digunakan yaitu sampel tanaman jagung. Alat adalah wadah plastik, kuas, pinset, kuas, mikroskop , kamera dan alat tulis menulis.

\section{Pelaksanaan Penelitian}

Metode penelitian menggunakan survey secara purposif sampling dengan menentukan pola scouting pada pertanaman jagung pada fase generatif dan vegetatif. 
Pelaksanaan penelitian dengan melaksanakan pengamatan pada bagian tanaman dengan mencari bekas gigitan, dan bekas gerekan pada bagian daun dan batang. Fase perkembangan serangga yang dapat ditemukan dilapangan yaitu telur, larva, pupa, serta imago. Spesimen yang diperoleh dilapangan akan di rearing untuk dilakukan identifikasi. Pelaksanaan identifikasi dapat dilakukan dengan mengamati ciri khas berdasarkan kunci determinasi (Sharanabasappa.2018 dalam (Maharani et al., 2019). Parameter pengamatan yaitu deteksi keberadaan $S$. frugiperda di pertanaman jagung.

\section{HASIL DAN PEMBAHASAN}

Berdasarkan hasil penelitian ditemukan bahwa $S$. frugiperda telah menyerang tanaman jagung di Kelurahan Talotenreng, Sompe, Walennae, Desa Liu, Ugi, Ujung Pero, Wage, Worongge, Salotengga, Pallimae, Mallusesalo, Pasaka, Tadangpalie, Benteng lompo. Stadia serangga yang ditemukan yaitu larva, dan imago.
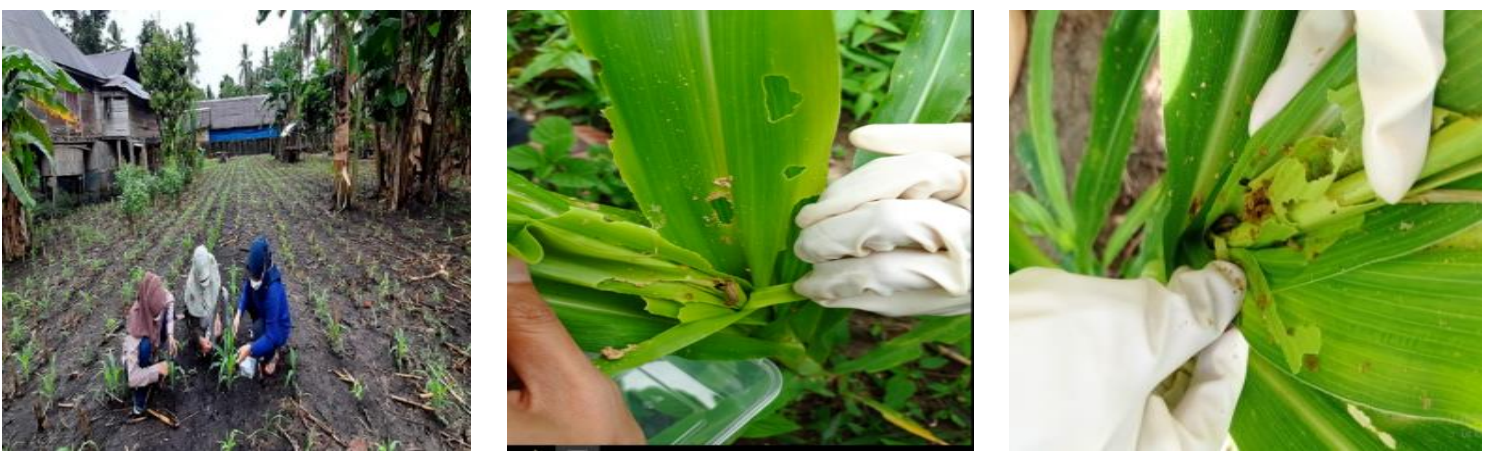

Gambar 1 . (a) Pengamatan gejala serangan S.frugiperda, (b) larva S.frugiperda, (c) gejala serangan dan sisa feses larva S.frugiperda

Hasil penelitian menunjukkan bahwa seluruh kelurahan dan desa lahan jagung ditemukan serangan $S . \quad$ frugiperda menyerang seluruh stadia tanaman jagung. Hal ini sesuai dengan pendapat yang dikemukakan oleh (Pebrianti \& Siregar, 2021) yang menyatakan bahwa $S$. frugiperda menyerang tanaman jagung pada saat fase pertumbuhan tanaman jagung mulai dari fase vegetatif sampai dengan fase generatif. Bagian tanaman yang diserang pada fage generatif dan vegetatif pada bagian pucuk tanaman jagung, daun yang terbuka, hingga ada yang terdapat pada tongkol jagung.

Gejala awal pada tanaman ditandai dengan adanya hilangnya lapisan epidermis daun sehingga daun terlihat transparan. Biasanya banyak larva instar 1 akan 
Perbal: Jurnal Pertanian Berkelanjutan

Fakultas Pertanian Universitas Cokroaminoto Palopo

bergerombol (FAO \& CABI, 2019). Gejala selanjutnya juga dapat dideteksi melalui sisa kotoran feses larva. Sementara larva dapat ditemukan pada bagian daun (Pebrianti \& Siregar, 2021). Larva instar 1 awalnya memakan jaringan daun dan meninggalkan lapisan epidermis yang transparan. Larva instar 2 dan 3 membuat lubang gerekan pada daun dan memakan daun dari tepi hingga ke bagian dalam. Larva instar akhir dapat menyebabkan kerusakan berat yang seringkali hanya menyisakan tulang daun dan batang tanaman jagung. Kepadatan ratarata populasi $0,2-0,8$ larva per tanaman dapat mengurangi hasil $5-20 \%$ (Nonci et al., 2019).

Menurut FAO \& CABI (2019) dan Subiono (2019), S. frugiperda bersifat polifag. Kisaran inang seperti jagung, padi, gandum, sorgum, dan tebu (FAO \& CABI, 2019). Berdasarkan uji preferensi pakan $S$. frugiperda menyukai tanaman jagung, padi dan tanaman rumput baciaria (Subiono, 2019). Larva S. frugiperda memiliki kemampuan makan yang tinggi. Larva akan masuk ke dalam bagian tanaman dan aktif makan, sehingga bila populasi masih sedikit akan sulit dideteksi. Imagonya merupakan penerbang yang kuat dan memiliki daya jelajah yang tinggi (FAO \& CABI, 2019). Larva S. frugiperda bersifat kanibal hal ini sesuai dengan pendapat (Nonci, 2019) yang menyatakan bahwa larva FAW mempunyai sifat kanibal sehingga larva yang ditemukan pada satu tanaman jagung antara 1-2, perilaku kanibal dimiliki oleh larva instar 2 dan 3.

Keberadaan dan populasi serangga $S$. frugiperda kemungkinan dipengaruhi oleh ketinggian tempat. Larva $S$. frugiperda hanya ditemukan pada lokasi survei dengan ketinggian sekitar 700-850 mdpl (Lubis et al., 2020). Sabbangparu memiliki Garis Lintang (0) 4.21, Garis Bujur (0) 120.01, Ketinggian dari Permukaan Laut (m) 29 (BPS, 2020).

\section{KESIMPULAN}

S. frugiperda telah menyerang tanaman jagung di semua Kelurahan dan Desa di Kecamatan Sabbangparu pada generasi generatif dan vegetatif. Karakter spesifik yang terdapat pada $S$. frugiperda berupa huruf "Y" terbalik pada kapsul kepala dan pola titik hitam pada abdomen (titik empat dan trapesium). Stadia pertumbuhan yang diperoleh dilapangan yaitu stadia larva dan imago.

\section{DAFTAR PUSTAKA}

BPS, K. W. (2020). Kecamatan Sabbangparu dalam angka 2020. Diakses pada tanggal 29 September 2020.

FAO, \& CABI. (2019). Community-Based Fall Armyworm monitoring, early warning and management: Training of Trainers Manual. 
Volume 10 No.1 Februari 2022

ISSN 2302-6944,e-ISSN2581-1649

Diakses pada Tanggal 17 September 2019.

Lubis, A. A. N., Anwar, R., Soekarno, B. P., Istiaji, B., Sartiami, D., Irmansyah, \& Herawati, D. (2020). Serangan Ulat Grayak Jagung (Spodoptera frugiperda) pada Tanaman Jagung di Desa Petir, Kecamatan Daramaga, Kabupatem Bogor dan Potensi Pengendaliannya Menggunakan Metarizhium rileyi. Jurnal Pusat Inovasi Masyarakat, 2(6), 931-939.

Maharani, Y., Dewi, V. K., Puspasari, L. T., Rizkie, L., Hidayat, Y., \& Dono, D. (2019). Cases of Fall Army Worm Spodoptera frugiperda J. E. Smith (Lepidoptera: Noctuidae) Attack on Maize in Bandung, Garut and Sumedang District, West Java. CROPSAVER - Journal of Plant Protection, 2(1), 38. https://doi.org/10.24198/cropsaver.v2i1.23 013

Nonci, N., Kalgutny, Hary, S., Mirsam, H., Muis, A., Azrai, M., \& Aqil, M. (2019). Pengenalan Fall Armyworm (Spodoptera frugiperda J.E. Smith) Hama Baru pada
Tanaman Jagung di Indonesia. In Badan Penelitian dan Pengembangan Pertanian Balai Penelitian Tanaman Serealia (Vol 73).

Pebrianti, H. D., \& Siregar, H. M. (2021). Serangan Ulat Grayak Jagung Spodoptera frugiperda (Lepidoptera: Noctuidae) pada Tanaman Jagung di Kabupaten Muaro Jambi, Jambi Attack of Corn Spodoptera frugiperda Caterpillars (Lepidoptera: Noctuidae) on Corn Plants in Muaro Jambi Regency, Jambi. Agrohita, 6(1), 31-35.

Sari, K. K. (2020). Viral Hama Invasif Ulat Grayak (Spodoptera frugiperda) Ancam Panen Jagung di Kabupaten Tanah Laut Kalsel. Jurnal Proteksi Tanaman Tropika, 3(03), 244-247.

Subiono, T. (2019). Preferensi Spodoptera frugiperda (Lepidoptera: Noctuidae) pada Beberapa sumber Pakan. Jurnal Agroekoteknologi Tropika Lembab, 2(2), 130.https://doi.org/10.35941/jatl.2.2.2020.2 813.130-134 